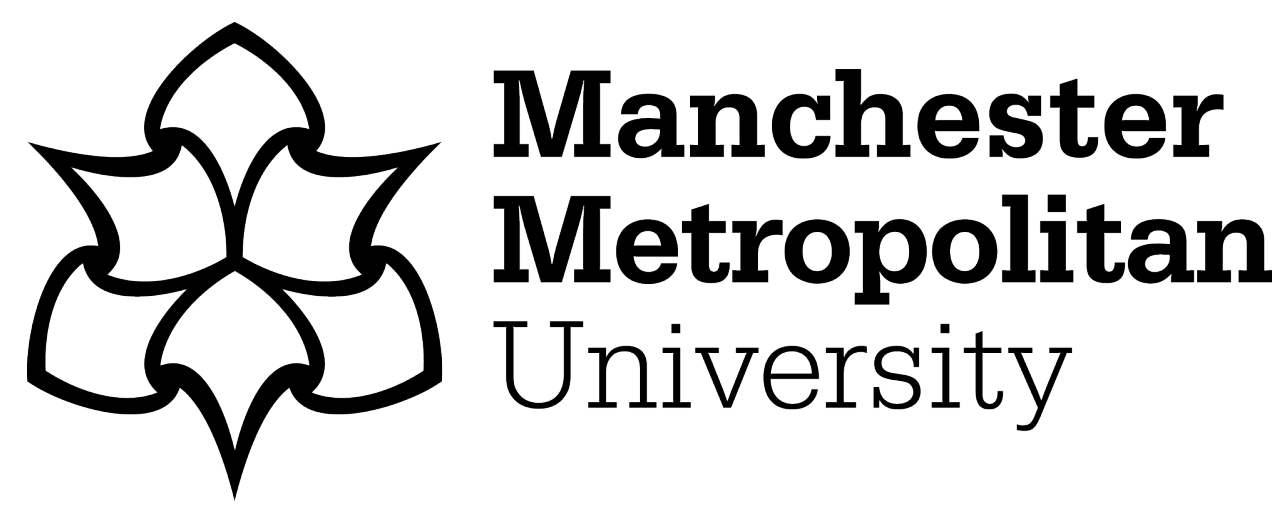

Milestone, Katharine ORCID logoORCID: https://orcid.org/0000-0001-72915881 (2018) Swinging regions: Young women and club culture in 1960s Manchester. Film, Fashion and Consumption, 7 (2). pp. 179-194. ISSN 2044-2823

Downloaded from: https://e-space.mmu.ac.uk/622863/

Version: Accepted Version

Publisher: Intellect

DOI: https://doi.org/10.1386/ffc.7.2.179_1

Please cite the published version 


\title{
Swinging regions: Young women and club culture in 1960s Manchester
}

\section{Katie Milestone}

\section{Manchester Metropolitan University}

\begin{abstract}
This article examines the ways in which women accessed elements of a 'Swinging Sixties' lifestyle, outside of London. This article is based upon interviews with women who actively participated in Manchester's coffee club and discotheque scene in the mid-1960s. I explore the gendered dynamics of the cultural north/south divide and the ways in which girls in the regions carved out access to the style and experience of the 'Swinging City', dispelling the popular myth of this being exclusively attached to London. The interview data reveal high levels of creativity and agency and I explore the ways in which encounters with popular culture, notably night clubs, pop music and fashion, impacted on the women's wider life choices and experiences. I also reflect on cinematic representations of young women in England in this period and the spatially motivated discourses pertinent to the case study.
\end{abstract}

\section{Keywords}

teenage girls

'Swinging Sixties'

Manchester

night clubs

coffee clubs

pop music

fashion

media 


\section{Introduction}

This article examines the ways in which young women accessed elements of a 'Swinging Sixties' lifestyle, outside of London. This article is based upon interviews with women who actively participated in Manchester's coffee club and discotheque scene in the mid-1960s. I explore the gendered dynamics of the cultural north/south divide and the ways in which girls in the regions carved out lifestyles and experiences of the 'Swinging City', dispelling the popular myth of this being exclusively attached to London. I also reflect on cinematic representations of young women in England in this period and the spatially motivated discourses pertinent to the case study.

An overemphasis on the pop culture of 'Swinging London', particularly by the media, is responsible for the scarcity of literature that explores what was happening in other cities in the United Kingdom in this period. To what extent were young people, notably young women, able to emulate and express aspects of this new form of lifestyle and identity if they were not part of the metropolitan glitterati? To explore this question this article reflects on what pop cultural opportunities were available contemporaneously to the 'Swinging London' era (approximately 1964 to 1967) in the city of Manchester in the north of England. This article probes documentary evidence, media artefacts and existing academic/non-academic studies of Manchester in this period. In addition, the article is informed by data from interviews with three women who actively participated in Manchester's coffee club and discotheque scene in the mid to late $1960 \mathrm{~s}$.

It is certainly the case that London was at the centre of an exceptional moment of cultural innovation in the mid-1960s and this has been well explored (see Levy 2002 and Bayley 
2012). However, I seek to demonstrate that new, youth-orientated lifestyles were not entirely contingent on geography. The social and cultural changes that happened in the mid-1960s, particularly connected with the media and greater social and physical mobility, saw the possibilities of new lifestyles to spread across time and space. In particular, the article is interested in exploring how young women who were geographically peripheral (to London) still accessed and experienced what might be described as a 'Swinging Sixties' lifestyle. Key aspects of this lifestyle for young women include opportunities to participate in leisure activities in the night-time economy, consumption of new pop cultural products, greater social and physical mobility and a loosening of social codes around premarital sex. The 'swinging' lifestyle can be linked to the process of individualization, identified by Giddens (1991) and Featherstone (2007), as a dominant subject position in late modernity. Similarly, those individuals at the heart of the cultural production of the 'Swinging City' can be understood in terms of Bourdieu's work on new cultural intermediaries, summarized by Featherstone as being 'fascinated by identity, presentation, appearance, lifestyle and the endless quest for new experiences' (2007: 44). Through a combination of a new infrastructure supporting pop cultural consumption and 'do it yourself' practices, young women in Manchester were able to forge pop culturally inspired identities.

\section{Periphery/region}

There are enduringly powerful ideas about the 'Swinging Sixties' and its location. London was undeniably the site of ground-breaking and fresh pop cultural creativity and an important site for the congregation of creative pioneers (many of whom did not originate from London). Spatially located around Soho and Chelsea (see Ryecroft 2002), the 'scene' comprised of night clubs, boutiques, restaurants and homes of key players and fuelled in part by the freedoms and innovations emanating from London's art colleges (Frith and Horne 1987). 
Some saw what was happening in London as the arrival of a 'swinging meritocracy' (see Hewison 1997), celebrating an alleged new mixing of classes, whilst others, notably Booker (1969), were more cynical about the claims that class divisions were being broken down and being replaced by growing generational divisions.

In terms of 'Swinging London's' relationship with the rest of the county, the North and other British regions were typically positioned as places that needed to be escaped from. The North was frequently imagined as a parochial, friendly but dull place, with little to offer culturally. However, just a few years before the invention of Swinging London, 'the North' of England had begun to be represented and discussed in new ways, most famously the novels, plays and subsequent 'New Wave' of films set in and about the North of England that prioritized working-class youth, notably A Taste of Honey (Richardson, 1961), A Kind of Loving (Schlesinger, 1962) and Billy Liar (Schlesinger, 1963). These films have a common narrative of showing young people trapped in a hum-drum and often stifling context, rebelling against the older generation and expressing dissatisfaction with their environment (Higson 1984; Hill 1986). There is little in representational culture to suggest the possibility of glamour and excitement in the regions. According to cinematic representations, glamour and cool are the preserve of the capital city.

Crucially from 1963 onwards, the dominant focus for films aimed at and about young people in the 1960s moved to London. Notable examples included two films starring The Beatles, $A$ Hard Day's Night (1964) Help! (1965), The Knack (1965) - all directed by Richard Lester, Blow Up (Antonioni, 1966), Alfie (Gilbert, 1966) and Georgy Girl (Narizzano, 1966). Filmmakers were drawn to London and its novel and daring new lifestyles and the visual spectacle of the pop culture of London. There are recurring narratives in these films that London is the 
location for innovations in fashion, pop and youth culture, although most of these films also allude to the dangers of London. 'Swinging London' was represented as offering new choices and freedoms, but also as a potentially dangerous place for young women. There was certainly a centre/periphery dichotomy at play and geographical differences were frequently accentuated. In the film Alfie, Alfie complains that the northern character Annie (played by Jane Asher) is bloating him out with her 'pies'. In Smashing Time (1967) Northern girls, Brenda (Rita Tushingham) and Yvonne (Lynn Redgrave) struggle to cope with London's sophistication. Pamela Church Gibson observes that these films

did their best to undermine any illusions about Swinging London. Rita Tushingham in The Knack (1963) played a provincial girl who comes to London in search of the 'scene' she has read about - a copy of Honey is in shot as her train nears London- and she is swiftly disillusioned. (2006: 95)

The media told the world that London was the place to be, whilst concurrently telling women to be wary about the alleged risks of this city. There are powerful ideas about space and place alluded to in many of this group of films around centre/periphery, familiar/strange and risk/safety, and these have particular implications for women. This article challenges the idea that the regions and regional cities were uniformly bland and frustrating for young people to operate in the mid-1960s. New ways of living, and exciting new leisure opportunities, were available in regional cities such as Manchester. In the mid-1960s a number of cutting-edge and exciting youth cultural spaces started to open up the regional British city of Manchester, as they did in many other 'regional' places. 


\section{Swinging Manchester}

Mid-1960s Manchester had all the elements to nurture a new youth culture. It goes without saying that Manchester and London were very different places in this period. As the capital city, London benefitted from a range of institutions, cultural assets and wealth that were not present in Manchester. As Breward notes of Swinging London: 'For all the talk of a supposedly meritocratic new order, it is instructive to recall how many young "honourables" were the proprietors or backers of cutting-edge boutiques, trattorias and galleries' (2006: 16). Manchester was not the site of palaces and princesses, or the playground of the landed aristocracy. Swinging Manchester was predominantly working class (but not exclusively so), but with its media institutions, higher education provision, abundant night time leisure infrastructure, transport links and new cultural intermediaries, it had a generous smattering of the elements required to lead a contemporary youth lifestyle.

In the late 1950s and the early 1960s, the North (of England) developed a powerful new cultural identity, often centred on young people. This came from fictional representations (see Higson 1984; Hill 1986) and the rise of northern pop groups - most notably, The Beatles. The 1950 s and the 1960s were decades in which working-class people became involved in cultural production and in which the value and status of popular culture began to be redefined. This was directly connected to the rise of educational opportunities for workingclass children, who, often via Grammar Schools, gained places at University. This new identity was strongly connected with youth culture.

One of a plethora of now iconic media images of the Swinging Sixties is the closing sequence of BBC television show chat show, Dee Time. (1967-1969). ${ }^{1}$ The closing shot focuses on 
(pirate radio) DJ and television presenter Simon Dee, driving an E type Jaguar down the spiralling exit route from a modern car park. A 'dolly bird' clad in a black PVC raincoat and white knee length boots is shown hopping into Dee's car as he speeds off down the ramp way. Dee is not in this closing sequence, as might be expected, in London. The location is the car park of Manchester's Piccadilly Plaza Hotel (which was completed in 1965). The city of Manchester, famous for its grimy mills and imposing Victorian civic buildings, is far less often considered in terms of its post-war modernist structures. However, there were a number of adventurous modernist structures in 1950s and 1960s Manchester (see Brook 2017). The Piccadilly Plaza complex offered a fittingly modern backdrop for key media products of the mid-1960s, and as Flynn (2018) notes, was also a location used in Charlie Bubbles (Finney, 1967) and Billy Liar (1963), where 'Julie Christie strolls across the concrete mega-structure [...] and everybody else' (Flynn 2018). Whilst the closing credits of Dee Time represent a fabricated example of the Swinging Sixties, full of cliché and hyperbole, they also hint at the idea that Manchester has some of the spaces, people and infrastructure to compete with the dramatic cultural changes happening in the London scene. Dee Time was first broadcast in 1967, at the tail end of the Swinging Sixties period, and was a chat show aimed at young audiences. Its opening episode included Jimi Hendrix performing Purple Haze and the show was broadcast from Manchester twice a week from April 1967 to September 1967, when production moved to London until the programme folded in 1969. Dee Time was not the only youth television programme being broadcast from Manchester; Top of The Pops (19642006)) was filmed in the city from 1964 to 1966 and this meant that the most successful pop performers of the age came to Manchester, albeit fleetingly. Granada Television, housed in another of Manchester's ambitious modern buildings, was a powerful and innovative independent TV company (see Kelly and Jones ${ }^{2}$ and Cooke, 2017). Manchester had a flourishing media industry in the 1960s (including being the base for northern offices of 
national newspapers). The city was the base for 'new cultural intermediaries' (Bourdieu 1984) and attracted a number of visiting glamorous actors, television presenters and musicians. Manchester was increasingly mediated in both fictional and factual forms and its home-grown pop stars and celebrities gave the city a flavour of cosmopolitan glamour and style.

Manchester also had an additional asset to its glamour capital, which came via football. Mellor (2000) points out that something new was happening in the way that football and football players were constructed and received in the mid-1960s. Manchester United FC, and one player in particular, were at the heart of this;

Manchester United were par excellence the football club which connected most closely with the burgeoning popular culture of the north of England in the early 1960s. Not only were they successful in that period, but they had players, most notably George Best, whose dress sense, style of play and anti-establishment character matched exactly the mood of the time. (Mellor 2000: 162)

The tabloid press christened Best 'El Beatle' and a 'connection between United and Britain's stylish youth culture was made' (Mellor 2000: 162). A media moment that succinctly captures Best's pioneering status as 'rock and roll footballer' is when he was filmed as an audience member watching The Rolling Stones performing their single, The Last Time, in $1965^{3}$ at a live studio recording for Top of The Pops in Dickinson Road, Manchester. George Best was pivotal in injecting glamour into Manchester, a 'man about town' who was frequently photographed in the newly emerging leisure spaces of Manchester, including his 
own fashion boutique, Edwardia. With the abolition of the cap on footballer's wages and a subsequent rise in salaries a new type of celebrity footballer emerged.

That Top of The Pops was filmed in Manchester during those key years of the mid-1960s (1964-66) means that it could be considered, during that time, as the north's answer to London's Ready, Steady, Go! (RSG!) (1965-67). Both shows attracted key chart-topping acts of the day and allowed young people to participate as audience members. Through watching both the bands and audience members on television, young people across the British Isles could see what was fashionable and new in terms of clothes, hairstyles and dance styles. As Tebbutt notes of youth television shows such as $R S G$ ! they 'brought immediacy and speed to the dissemination of youth styles and contributed to a much stronger sense of shared youth identity' (2016: 154). Young people across the United Kingdom could see 'Swinging London' in their living rooms.

In addition to pop television shows, powerful fictional representations of Manchester and Salford were being beamed across the county via Granada Television's seminal soap opera Coronation Street (1960 onwards). The soap opera was a new television genre and its focus on the minutiae of working-class life was ground-breaking at the time. The programme focused on the contrasts between the older generation and young people, for example, the teenage character, Lucille Hewitt, who was described by Osuh (2007) as a 'footloose, Swinging Sixties teenager'. Jenny Moss, the actor who played Hewitt, briefly left the show to star in Live It Up (Comfort, 1963), a film with David Hemmings and Steve Marriot (later of the band The Small Faces) about a beat group. Davy Jones, arguably the most popular member of US boy band The Monkees, was from Gorton, Manchester, and had been a child actor on Coronation Street, as too had Peter Noone of Herman's Hermits. The city was also 
the location of a number of films during the 1960s. These include Hell Is a City (Guest, 1960), A Taste of Honey (Richardson, 1961), A Kind of Loving (Schlesinger, 1962) and Charlie Bubbles (Finney, 1967).

Manchester had a notable presence in terms of its pop bands that gained national and international success (although not to the extent of neighbouring Liverpool). The Hollies, Herman's Hermits and Wayne Fontana and the Mindbenders are the most well-known Manchester bands of this era. These groups played a significant role in the beat boom and the 'British Invasion' of the United States. Wayne Fontana and The Mindbenders supported James Brown, and had a number one hit in the United States in 1965. Significantly for the subsequent musical fortunes of the Manchester area, Peter Tattersall, a former road manager for Billy J. Kramer (from Liverpool) and the Dakotas (from Manchester), and Eric Stewart, then lead guitarist and singer of the Mindbenders, opened state-of-the-art recording studios in Stockport (Greater Manchester) in the late 1960s (Wadsworth 2007). The Hollies had considerable success and spent 231 weeks on the UK singles charts during the 1960s. Herman's Hermits had a number of top ten hits between 1965 and 1967 in both the United Kingdom and United States. This helped lay the seeds of a music industry infrastructure that benefitted subsequent Manchester bands greatly.

The city had a remarkable number of night clubs for young people (see Lawson 1990), such as the Oasis (the inspiration for the Gallagher brothers for the name of their band) and The Twisted Wheel. The clubs were not only used by local bands but by international bands on tour. For example, the Abadi brothers, who established the Twisted Wheel club, booked international soul and R\&B acts such as Ike and Tina Turner. 
In the early and mid-1960s British bands frequently toured the towns and cities of the United Kingdom, sometimes doing several performances a day. Both well-known and up and coming pop acts toured the towns and cities of the United Kingdom extensively. The Beatles and the Rolling Stones gave several performances in Manchester - especially between 1963 and the end of 1965 . However, London was undoubtedly where the British pop stars gravitated to and ended up living (although after the mid-1960s many began to move to the countryside and the United States). Aside from pirate radio (see Chapman 1992), watching live acts was one of the only way that young consumers could get to hear new music. BBC Radio 1 did not start broadcasting until 1967 and pop music was difficult to access on mainstream radio shows. In many respects the Swinging Sixties was mobile, on tour and left traces of pop cultural innovations in its wake. Manchester benefitted greatly from this.

\section{Teenage girls and young women in mid-sixties Manchester}

This section includes a discussion of interviews with three women who were teenagers in the mid to late 1960s. Specifically the interviews focused on women's experiences of going to coffee bars, nightclubs and concerts. Although a wide variety of Manchester's clubs were frequented, the Twisted Wheel was pivotal to all three interviewees. The interview data reveal high levels of creativity and agency amongst the women and the interviews explore the ways in which encounters with popular culture, notably night clubs, pop music and fashion, impacted on their wider life choices and experiences. All three of the women who were interviewed came from working-class backgrounds. One stayed on at school to do A levels but did not go to university until later in life. The other two left school at 15 and went straight in to employment. One of these women also went into higher education later in life. One was a hairdresser who moved abroad in her early 20 s to work as a travel rep. Another worked as a 
go-go dancer for a short time in the late at the Arthur Fox Revue club (a striptease club) that had opened in 1959. Two of the interviewees lived in the Manchester area whilst the third was from Telford (West Midlands), but travelled to attend Manchester's Twisted Wheel. The fact that this woman was drawn to Manchester, not London (both were equally as hard to get too from her home-town), suggests that Manchester had something significant to offer young people. By the late 1960s all of the women had left their homes for a spell of travelling and taking up casual jobs in other parts of the country (one travelled abroad). The fact that all three of the women travelled suggests an adventurous spirit that may have been partly been inspired by their engagement with exciting new youth and pop culture. There was a consensus and awareness that the Manchester that they experienced in their youth was exciting and full of entertainment and opportunity for young people.

Penny Tinkler's (2014) research on magazines aimed at teenage girls notes a distinct shift in their tone and focus from 1963. Tinkler's work is of great relevance as 1963 is when the women interviewed here started to go out and engage with new lifestyle possibilities. Her research on key teenage magazines of the era, notably Honey and Petticoat, shows that there is a new subject position being laid out for girls and young women, 'a late-modern selfcharacterized by emphasis on choice, fulfilment, self-discovery, self-realization and selfreflexivity' (Tinkler 2014: 598), albeit with a number of residual constraints and frustrations. Petticoat (launched in 1965) was particularly aimed at the young, independent woman and included features on the standard fashion, beauty and pop celebrities but also '[...] film, music and cooking. Readers were assumed to be either living at home or independent [...] Sexual relationships were a prominent theme and dealt with candidly' (Tinkler 2014: 600). As these publications were available across the country girls in the regions were able to engage with these new ideas about young female identities. 
As discussed above, a regional city such as Manchester showed signs of the cultural transformations fetishized in swinging London. As interviewee B pointed out people from outside of the immediate conurbations travelled to Manchester to sample its youth culture; 'Manchester was a brilliant place. I think Liverpool and Manchester were quite unique at that time, people definitely used to travel in'. Interviewee A gives a clear sense of the opportunities for 'going out' offered in the Manchester in the early to mid-1960s:

I started going to clubs in 1962. We were spoilt for choice. They were all quite close to Albert square, apart from the Jungfrau. I saw so many bands. There was the Mogambo on Mosley Street, the Twisted Wheel, The Two Jays [...]. which changed to the Oasis. The Three Coins on Fountain Street, Bodega, Guys and Dolls, Jungfrau - they were the main ones and the Kardomah coffee bar. Shudehill was brilliant, lots of streets and shops. Musicians came to Manchester before they were famous - there was a lot of Blues, people like Howlin' Wolf.

This quote gives a strong sense of the richness of pop music and club culture available to young people in this period.

The Twisted Wheel was a prime example of the sort of exciting new spaces that were springing up in Manchester in the early to mid-1960s. There are two significant explanations for the sheer number of clubs opening in this period. First, the gradual replacement of the bandstand with the DJ booth that was happening in this period also saw a diminishing requirement for space. New dance styles and technological innovations changed the 
requirements for the space needed to dance. Less space was needed for dancers and DJs, and so the demise of the ballroom was brought about by the arrival of more informal dance styles. Spacious ballrooms (such as Manchester's Ritz) that, as Langhamer's (1999) research shows, had been important leisure spaces for unmarried women were waning in popularity. New types of clubs were opening up in smaller spaces, often in cellars. There was a lot of choice and more differentiation in these new, informal and less panoptic spaces. Ballroom dancing in the early 1960s had not entirely slipped out of view, but it was something aimed at all ages. People learnt to dance at school or with their parents, as interviewee A noted: 'We used to go as a family to the Elizabethan at Bellevue, our parents taught us how to dance'. The new coffee clubs were spaces where people danced in new individual ways, in dark and cramped spaces, where sweat poured down the walls. These were not spaces that you would go to with parents, not least because of the high levels of drug taking happening in these clubs. The second major factor driving the opening of coffee dance clubs was that it was a way of circumventing 'red tape'.

For all three interviewees going to The Twisted Wheel was an important and defining experience. The Twisted Wheel was a remarkably exciting and cutting-edge place that was distinct and unique in many ways, with its showcasing of freshly imported records, adventurous DJ and booking of hugely talented bands. Interviewee A went to the original site of the club on Brazennose Street (which opened in 1963) and to the new site for the club on Whitworth Street (1965). The Twisted Wheel was a club in which new styles of solo dancing were taking place. For girls and boys new solo dance styles dispensed with the constraints and formalities of partner dancing (Milestone 2018). Dancing could be more spontaneous and to previously unavailable music, which contrasted starkly with the mainstream popular music of just a few years earlier. On the dancefloor, at least, young 
women no longer had to be given permission to enter. As McRobbie argues; 'Dance is where girls were always found in subcultures. It was their only entitlement' (1994: 168). All the women who were interviewed spoke of the value and enjoyment that they got from dancing and the way in which groups of boys and girls socialized on and around the dance floor. It is clear that women were experimenting with new fashions and dispensing with traditional 'feminine' styles. Interviewee B recalls; 'I wore Levis or Wranglers, a tight top and flat, slippery shoes. We dressed like the lads. It was practical for dancing. We just went to dance'. All girls described themselves as Mods and the style that the interviewee above describes resembles Mod styles. She said she minimized her bust as much as possible for both practical and aesthetic reasons to fashion an androgynous look. Ivor Abadi (in Keane and Quinn, 2010) noted the distinctive styles of girls at the Twisted Wheel in a press interview

They were very smart and different. The girls used to wear duffle coats, which were very popular. And there was a period when they wore long gloves, which were very trendy and fashionable. The style of the people who came to the club was a bit exaggerated and unconventional $[\ldots][\ldots]$ They would also make their own badges uniting themselves to each other.

Abadi's reference to the word 'unconventional' sums up that the clientele of a club like the Twisted Wheel were 'alternative', bohemian, willing to take risks and try new experiences. Interviewee A recalled that in the 1963-65 period she and many of her peers made their own clothes. This is hardly surprising, given Greater Manchester's heritage as a site of cotton mills, hatting and so forth. Lots of women were experienced dress makers. In the 1960s the arrival of new fabrics such as Bri-nylon and Crimplene were particularly easy to work with. 
Interviewee A described how she would purchase some fabric from Stockport market and make a dress the same day and that people who lacked sewing skills would employ a local dress maker. She also recalled the speed with which hemlines started to rise; 'We were lopping inches off our skirts'. There was a strong culture of home-made fashions in this period, and teen magazines often included dress patterns. Pattern companies caught on to youth styles and as Gilbert notes 'Designers such as Quant and Gerald McCann produced pattern designs, with one Quant for the Butterick company selling 70,000 copies' (2006: 117). Furthermore there was the possibility to buy the latest London fashions via mail order. David Gilbert's work is pivotal in reminding us that the trappings of 1960s London found their way elsewhere. Biba was available via mail order and Honey magazine opened up regional boutiques. Gilbert highlights the fact that 'One of the features of the 1960s was the extent to which a relatively circumscribed London scene rapidly entered national mythologies, and how many people wanted some material connection to it' (2006: 117).

Interviewee $\mathrm{C}$ spoke of the importance of being able to 'get out' of the domestic sphere and that the bedroom was not a sanctuary but a cramped and noisy space that you had to share with other siblings. For young people living in modest, fairly compact, homes it was a great advantage to be able to go out and explore the outside world. Interviewee $\mathrm{C}$ travelled up from Telford to Manchester at the weekends either by train, a lift or hitchhiking. She worked in a factory and her peers were fascinated by the stories of her visits to Manchester and 'who couldn't comprehend that you'd go that far to go out'.

During the early to mid-1960s interviewee A accessed the clubs of central Manchester by bus. It was also possible to travel home via this mode of transport: 'there was a night bus. It was quite fun on the bus, very sociable - we never got a taxi, it felt very safe for girls'. All 
interviewees spoke about how easy it was to get in to central Manchester via public transport. Manchester's compact city centre made access to the fruits of its night time economy very easy. There were lots of clubs in close proximity and the city offered good transport links including four city centre train stations, a good bus network and an international airport.

With the arrival of the juke box in the 1950s (see Horne 2009), the coffee bar became an important social space for young people. For girls these were a particularly attractive space because, as one interviewee noted, 'girls couldn't go in pubs'. Another interviewee recalled that the Kardomah coffee bar stayed open late into the evening and was only frequented by young people, most of whom were mods. By the mid-1960s the Kardomah and the Cona Coffee bar were established as Mod hangouts and a starting point for a night out, described by one interviewee as a 'waiting room for the Twisted Wheel'. There are photographs taken by esteemed Manchester photographer, Shirley Baker, of a group of Mods outside the Cona Coffee bar in 1965. This image is of five young people, two of whom are female. This image supports the view of the women interviewed that there were strong, mixed-sex friendships. The young people are 'larking about', all looking happy and all are very stylishly dressed. The young women have short hair and one is wearing 'boyish' trousers and flat shoes whilst the other is wearing a knee-length leather coat. They boys are wearing button-down shirts, crewneck jumpers and boating jackets. The clothes worn are reminiscent of those worn in London in 1965, which suggests that teenagers in the regions were quickly able to emulate the most contemporary of styles.

The popularity of coffee bars with young people led to entrepreneurs opening up 'coffee dance clubs'. Describing a venue as a 'Coffee Club' was a way of subverting licencing laws 
and avoiding time-consuming red tape. Ivor Abadi (who established The Twisted Wheel club) describes the origins of the club:

The inspiration for the club was that young people needed a place to meet, listen to music, and dance. There were coffee bars in England at that time where people would meet, and they had music but no dancing. So we called our place a coffee dance club because there was no alcohol $[\ldots][\ldots]$ This was the baby-boom generation - people born in 1946, '47. There were a lot of young people, and they wanted something different. (in Keane and Quinn 2010)

The Abadi brothers imported blues and soul records directly from the United States. Abadi also cites local US Air Force bases as a route for cutting-edge vinyl reaching Manchester's youth and Jamaican music shops as another avenue for exciting new genres of music (Keane and Quinn 2010).

Mid-1960s Manchester offered a significant range of venues and consumption spaces for young people. These were far from parochial. The youth-orientated venues attracted the current and most exciting acts of the day from Britain and the United States and clubs such as The Twisted Wheel, particularly under the stewardship of DJ Roger Eagle, were introducing Manchester's young Mods to avant-garde soul records that were being imported directly from the States.

The Twisted Wheel and other coffee clubs were very much under the spotlight of law enforcement agencies in the mid-1960s. Louise A. Jackson's work on the 'coffee club 
menace' (2008) reveals the extent of this; 'Manchester was gaining 'a reputation of being a swinging city' but the police viewed the club culture associated with it - which they linked to drug misuse, sexual incontinence and juvenile delinquency - as a 'public scandal' (Jackson 2008: 290). Jackson scrutinized the records of Manchester's Women Police Department and found detailed records of both overt and covert visits by the Police to clubs including 'the Aurora Club, Beat City, the Cavern Club, the Cona, the Cosmopolitan, Dick Ewan's Beat Club, the Forty Thieves, Guys and Dolls, the Heaven and Hell Club, the Jungfrau, the Sovereign, the Pacific Coffee House, and the Twisted Wheel' (2008: 290). This roll call of Manchester's coffee clubs is, by no means, exhaustive but it reveals the range and choice of youth culture spaces in the city in the mid-1960s. As Jackson observes 'a minority of young women were clearly engaged in forms of behaviour that were viewed as 'dangerous', although not necessarily illegal, and were active participants in Manchester's nightlife' (Jackson 2008: 292). Interestingly, although the police view was that these coffee/beat clubs for young people were dangerous, Jackson's work finds evidence that young people experiencing abuse emanating from family life used the clubs as a place of refuge; 'the media focus on the lurid and the sensational; the construction of the night-time city in terms of the spaces of sexual danger deflected attention away from abuse within the home' (Jackson 2008: 299). Twisted Wheel owner, Ivor Abadi, noted that the Police actively asked them to stay open all night to avoid young people wandering the streets in the early hours of the morning. In a recent magazine interview Abadi stated that

Other clubs that served alcohol could only stay open until 2:00 a.m. But we were able to stay open all night because we didn't have alcohol. When we first started doing all-night sessions, we used to close at about 3:00 or 4:00 in the morning. But because a lot of people 
came on public transport, they had nowhere to go until their public transport started again. So the local police came to us and asked us if we'd stay open a little later so that people weren't wandering the streets. The police weren't pleased that people were coming from other towns and cities. (Abadi in Keane and Quinn 2010)

Here we see an example where the coffee clubs are both friend and foe of the police. Jackson also notes that parents did not necessarily have the same opinion of the police about the clubs and highlights an example where the police forced five girls (aged 15 and 16) to leave the Twisted Wheel and subsequent complaints 'by parents who said that 'their daughter was quite capable of looking after herself' and that they had given permission to attend' (2008: 300). This chimes with the findings of Todd and Young, who argue that parents of baby boomers were supportive of their children engaging with the exciting leisure opportunities that they themselves had not had on offer during their youth; 'Many parents, particularly mothers, took vicarious pleasure in their teenagers' leisure pursuits. Mothers were especially likely to view their children as agents of social change who would be able to lead lives different from, and more fulfilling than their own' (Jackson 2008: 463). My interviewees expressed these types of views of their own parents; one (A), for example, felt that 'My parents must have been very understanding, they weren't very liberated [...]. but very tolerant'. Interviewee $\mathrm{C}$ said that her parents did not know where she went or what she got up to but did not try to prevent her being away from the home as she was 15 and had a job that she always turned up for.

Young people in Manchester did not have to rely solely on mail order and someone's dress making skills to be fashionably dressed as a number of fashion boutiques opened in 
Manchester. Marnie Fogg (2003) examines boutiques in the regions, using Nottingham as a case study for a regional city that saw new boutiques (notably through the creative entrepreneurialism of Paul Smith) open up in the mid-1960s. In the same space as where the Dee Time sequence was shot, a boutique opened in 1961 called Polly of Piccadilly ${ }^{4}$. The opening up of new youth cultural retail spaces was not just restricted to central Manchester. The Greater Manchester town of Stockport in the mid-1960s for example had a boutique called The Toggery (which supplied clothes to bands including The Hollies) and a lifestyle boutique, Seven Miles Out. Specialist youth culture shops were starting to emerge in a range ofregional towns and cities, and in Manchester the most high profile boutiques were those opened by George Best. Best opened a boutique on Cross Street in the spring of 1966 and another in the suburb of Sale. A local newspaper report ${ }^{5}$ highlights that Best was no silent partner in his boutique business;

Reader Joyce Hausaman recalls she met George while shopping in the store. She said: 'I was trying on a coat in the sale and a young girl was serving me and he came and said how nice it looked and I really should buy it'.

Pygmalia boutique was another of Manchester's pop cultural shops in this period that attracted pop stars and celebrities.

A newly emerging phenomenon was the wave of hair salons that began to be established. Twigg and Majima note that 'During the 1950s and 60s hairdressers proliferated in the UK (Smith, 2008) providing distinctive salon-based styles centred on the weekly shampoo and set. This was the era of rollers, setting lotion, backcombing and hair lacquer' (2014: 28). One of the interviewees (A) became a hairdresser in Manchester and described how 
It opened up a new world. We did bobs, backcombed, back style. Artists from the strip clubs and transvestites came in to hairdressers. We also did elaborate hairstyles lots of curls and lacquer. Beehives. People would keep one style for the whole week.

Being a hair stylist was a new and creative career option and contrasted greatly with the factory work typically the staple of young working-class people in the North-West of England. The coffee bars, clubs, boutiques and hair salons that were aimed at young people provided an alternative, pop cultural infrastructure that allowed young women to explore new ways of living.

\section{Conclusion}

There is a relatively little known film set in Manchester, The White Bus (Anderson, 1967), based on a short story by Shelagh Delaney, which deals with the tension between London and the regions and that a critic in 1968 described as containing ' $[\ldots]$ occasional resemblances to the Beatles' Magical Mystery Tour, made eighteen months or so later [...]' (Millar 1968). It is a remarkable piece of cinema. A beautiful and stylish young woman, with a Cathy McGowan-inspired hairstyle, who is from the North but who is working in London, jumps on a train to visit her hometown for the day. The film has a slightly surreal quality and moves around Manchester's bomb sites, slum clearance sites and more progressive urban spaces. A documentary film about the making of this film suggests that the protagonist in the film is strongly linked to Delany herself and is representing a 'typical' provincial girl who works in London and returns, perhaps only occasionally and rather despondently, to search for her roots in rapidly changing Manchester. The film deals with the tension between forsaking the warmth and familiarity of a close-knit Northern community for the sophistication and 
stimulation of London. This yearning for the North expresses Delaney's own ambivalence about the push and pull between London and the North. In 1961 Delaney moved to London and recounted in a television documentary 'that her home town of Salford was 'like a horrible drug' from which she wanted to 'get away'. At the same time she 'loved' the 'street life' of the inner city; 'it takes years to build up all those friendships and talking to your neighbours', she said; when one moved away "it is all lost"” (Todd 2013: 201). The Manchester of Delaney's youth had changed somewhat by 1965 and offered a great deal more excitement. Whilst creative young people might have had to move to London to be involved in cultural production there were great opportunities for women to consume popular culture in a city like Manchester.

This article is an exploratory study that seeks to highlight the under-researched area of life for young women in Great Britain who lived outside of London, using Manchester as a case study. In particular, I am interested in the extent to which young women had access to a swinging lifestyle - albeit in a piecemeal way - in Manchester in the mid-1960s. An obsession with swinging London by the media has caused the British regional cities to be largely overlooked in these terms and it is uniformly assumed that outside of the metropolitan milieu that the rest of Britain was parochial and behind the times. However, restrictions to accessing swinging lifestyles were not necessarily contingent on geography. Barriers were more likely to be connected with parental restrictions and social expectations of the time. As Mills notes in her study of women's memories of their youth in the 1960s the 'post-war period and particularly the 1960s, witnessed new opportunities for British young women both in the workforce and as the ideas of late modernity encouraged them to pursue self-fulfilment and self-expression' (2016: 466). It was certainly possible to 'individualize' and develop an expressive city in a large city such as Manchester. Interviewee $\mathrm{C}$, who travelled a substantial 
distance to consume Manchester's youth culture, is an example of a young woman who saw these pop cultural pleasures from afar and worked out a way to access them.

Manchester offered ample opportunity in the mid-1960s for young people to lead hedonistic and expressive lifestyles. The look and feel of Manchester contrasted starkly with London and the demographics of who was involved in the swinging scene of both cities were very different. Manchester may not have attracted aristocrats, debutantes, models and film stars of the London scene, but the city had its own unique cultural assets and a rich and vibrant nightlife in its compact city centre.

The spatial location of the Swinging Sixties is a debate that surfaces frequently in film, television and literature. In his recent book about 1966, Savage highlights a discussion of the London/regions dichotomy in an article in Rave magazine where a reader writes in and asks for advice about whether she should leave home and move to London. The 'agony aunt's' response is to argue that 'it doesn't all happen in London, it happens where you want to make it happen [...] London swallows you up [...] there would be long, dull, lonely evenings in a dingy bed sitter' (Mills 2016: 160). This is a new 'risk society' dilemma facing young women. Do you have to go to London to 'make it' and live a full life? Discourses about the spatial inequalities in terms of the Swinging Sixties surface in Mills' recent work on women's memories of the 1960s. One case study woman felt that 'the swinging sixties did not happen in her small northern industrial town' whilst a Liverpool-based woman said that the atmosphere was 'free and easy' (Mills 2016: 475). Exciting new youth cultural modes of living were available in a patchy way. Furthermore, it is quite possible for a teenage girl to be geographically close to central London but prevented from going there by strict parents. Plenty of girls in the suburbs of London and home counties were as distanced from the 
'Swinging Sixties' as girls from the more peripheral regions. The women interviewed for this article did not yearn to go to London and felt that Manchester offered a wide range of entertainment opportunities. The women who were interviewed were highly positive about their engagement with the pop cultural infrastructure of 'Swinging Manchester'. They were able to access fashionable clothes and spend their evenings socializing with their peers in exciting new spaces, aimed only at their demographic group. They felt that Manchester was exceptionally exiting and did not yearn to go to London. They spoke of great friendships with girls and boys alike and parents who did not try to stand in the way of their leisure choices. Of course, the accounts of three women represent a small sample and cannot in any way represent a universal experience of young women in this period; however, the evidence suggests a Swinging Manchester nonetheless.

\section{References}

Anderson, Lindsay, (1967) The White Bus, United Kingdom, Woodfall Films.

Bayley, S. (2012), Swinging London: The Inside Story of the 60s Capital of Cool, London: Carlton Books.

Booker, C. (1969), The Neophiliacs: A Study of the Revolution in English Life in the Fifties and Sixties, London: Collins.

Bourdieu, P. (1984), Distinction, London: Routledge and Kegan Paul.

Breward,C. (2006), Introduction, Swinging Sixties, in C. Breward, D. Gilbert and J. Lister (eds), London: Victoria and Albert Publications. pp. 8-21 
Brook, R. (2017), Manchester Modern, Manchester: Manchester Modernist Society.

Castells, M. (1996), The Rise of the Network Society, London:Blackwell.

Chapman, R. (1992), Selling the Sixties: The Pirates and Pop Radio, London: Routledge.

Church Gibson, P. (2006), 'Myths of the swinging city: The media in the sixties', in C. Breward, D. Gilbert and J. Lister (eds), Swinging Sixties, London: Victoria and Albert Publications. pp.80-99.

Coronation Street (1960-present, United Kingdom: Granada Television).

Davis,Desmond (1967) Smashing Time, United Kingdom, Partisan Productions).

Dee Time (1967-1969, United Kingdom, British Broadcasting Corporation).

Featherstone, M. (2007), Consumer Culture and Postmodernism, 2nd ed., London: Sage.

Flynn, Hayley (2018), 'Piccadilly Plaza: Dreams without frontiers', http://www.theskyliner.org/blog-1/piccadilly-plaza. Accessed 15 August 2018.

Fogg, M. (2003), Boutique, London: Mitchell Beazley.

Frith, S. and Horne, D. (1987), Art into Pop, London: Methuen.

Giddens, A. (1991), Modernity and Self Identity, Oxford: Polity. 
Gilbert, D. (2006), 'Out of London', in C. Breward, D. Gilbert and J. Lister (eds), Swinging Sixties, London: Victoria and Albert publications. Pp. 102-117.

Gilbert, Lewis (1966) Alfie, United Kingdom, Sheldrake Films

Hewison, R. (1997), Culture and Consensus in England: Art and Politics since 1940, London: Methuen.

Higson, A. (1984), 'Space, place, spectacle: Landscape and townscape in the "Kitchen Sink" film', Screen, 25:4\&5. pp. 2-21.

Hill, J. (1986), Sex, Class and Realism: British Cinema, 1956-1963, London: BFI.

Horn, A. (2009), Juke Box Britain: Americanisation and youth Culture, 1945-60, Manchester: Manchester University Press.

Jackson,L (2008) 'The Coffee Club Menace', Cultural and Social History, 5:3, pp. 289-308

Keane, M. and Quinn, B. (2010), 'Mod began here: The spot where '60s teens danced all night to Northern Soul music', Collectors Weekly, https://www.collectorsweekly.com/articles/an-interview-with-northern-soul-dance-clubproprietor-ivor-abadi/. Accessed 15 July 2018. 
Langhamer, C. (1999), 'Manchester women and their leisure: Changing experiences from youth to married adulthood, 1920-1960'. Manchester Region History Review, XIII, pp. 3242.

Lawson,A. (1990). It Happened in Manchester: The True Story of Manchester's Music 19581965, Bury:Multimedia.

Levy, S. (2002), Ready, Steady, Go! Swinging London and the Invention of Cool, London: Harper Collins.

McRobbie, A. (1994), Postmodernism and Popular Culture, London: Routledge.

Mellor, G. (2000), 'The genesis of Manchester United as a national and international "superclub” 1958-68', Soccer \& Society, 1:2, pp. 151-66.

Milestone, K. (2019), 'Soul boy, soul girl? Reflections on gender and Northern Soul', in S.Raine, T.Wall and N.Watchman Smith (eds), The Northern Soul Scene, Sheffield: Equinox.pp.197-216.

Millar, D. (1968), 'The White Bus', Sight and Sound, 37:4. pp. 205-06.

Mills, H. (2016), 'Using the personal to critique the popular: women's memories of 1960s youth', Contemporary British History, 30:4, pp. 463-83. 
Osuh, C. (2007), 'Fans mourn the death of Corrie's first wild child', Manchester Evening News, $15^{\text {th }}$ Feburary, https://www.manchestereveningnews.co.uk/news/greater-manchesternews/fans-mourn-death-of-corries-first-1044197. Date accessed: 11/08/2018.

Reports of Patent, Design and Trade Mark Cases Dorothy Perkins Limited v. Polly Perkins of Piccadilly Limited in the High Court of Justice-Chancery Division before Mr. Justice cross Dorothy Perkins Limited v. Polly Perkins of Piccadilly Limited (1962), 153 (No.6), 6 April.p.153

Ready, Steady, Go! (1963-1966, United Kingdom: Rediffusion-London).

Ryecroft, S. (2002), 'The geographies of swinging London', Journal of Historical Geography, 28:4, pp. 566-88.

Sandbrook, D. (2006), White Heat: A History of Britain in the Swinging Sixties, London: Abacus.

Savage, J. (2016), 1966: The Year the Decade Exploded, London: Faber and Faber. Tebbutt, M. (2016), Making Youth: A History of Youth in Modern Britain, Social History in Perspective), Basingstoke: Palgrave.

Tinkler, P. (2014), ““Are you really living?” If not, “Get With It!”, Cultural and Social History, 11:4, pp. 597-617. 
Todd, S. (2013), 'Class conflict and the myth of cultural "inclusion" in modern Manchester' in J. Wolff and M. Savage (eds), Culture in Manchester. Institutions and Urban Change since 1850, Manchester: Manchester University Press.pp.194-215

Todd, S. and Young, H. (2012), 'Baby boomers to "Beanstalkers"', Cultural and Social History, 9:3, pp. 451-67.

Top of the Pops (1964-2006, United Kingdom: British Broadcasting Corporation).

Twigg, J. and Majima, S. (2014), 'Consumption and the constitution of age: Expenditure patterns on clothing, hair and cosmetics among post-war "baby boomers"”, Journal of Aging Studies, 30, pp. 23-32.

Wadsworth, P. (2007), 'Strawberry Recording Studios and the Development of Recording Studios in Britain, c.1967-93', unpublished Ph.D. thesis, Manchester: Manchester University.

Wilson, D. (1968), 'White bus', The Monthly Film Bulletin, 35:408, p. 175.

\section{Contributor details}

Katie Milestone is a Senior Lecturer in Sociology at Manchester Metropolitan University. She has a long-standing research interest in women and popular music culture. Her research interests include the intersections between place, pop culture and gender. Katie has published work on 'northernness', Northern Soul and women and Manchester's creative industries. She is co-author of Gender and Popular Culture (2012), Polity Press. 
Contact:

Department of Sociology, Manchester Metropolitan University, Geoffrey Manton Building, Rosamond Street West, Manchester, M15 6LL. k.1.milestone@mmu.ac.uk

https://orcid.org/0000-0001-7291-5881

Notes

${ }^{1}$ The closing credits of Dee Time https://youtu.be/dpIEpf88N5w.

${ }^{2}$ Granadaland project http://www.granadaland.org/.

${ }^{3}$ George Best on Top of the Pops https://www.youtube.com/watch?v=27ouOE4RvUc.

${ }^{4}$ In 1962 the long-established clothes company Dorothy Perkins took the proprieter of 'Polly of Piccadilly' to court, claiming that their customers might think that the two separate companies were somehow connected;

The defendants, $[\ldots]$ recently decided to open a large self-service store at 7 Piccadilly, Plaza, Manchester, which would specialise in coats, suits, dresses, bridal gowns, skirts, slacks, jackets, knitwear, blouses and stockings for young ladies in the age group of fifteen to twenty-five years of age, and, apparently, this is intended to be the first of a nationwide chain of similar shops.

${ }^{5}$ https://www.messengernewspapers.co.uk/news/14147735.Memories_of_George_Best_s bo utique in Sale/. 